\title{
Pemanfaatan Survey GPS Geodetik untuk Pengamatan Deformasi Inter-seismik Setelah Satu Dekade Kejadian Gempa Bumi Bengkulu 2007 (Mw 8,4) di Daerah Bengkulu Bagian Utara
}

\author{
Ashar Muda Lubis ${ }^{1 *}$ \\ ${ }^{1}$ Jurusan Fisika, Fakultas Matematika dan Ilmu Pengetahuan Alam, Universitas Bengkulu
}

\begin{abstract}
Abstrak
Penelitian siklus gempa bumi sangat penting yang meliputi fase co-seismik, post-seismik dan interseismik untuk dilakukan. Penelitian ini bertujuan untuk mengamati deformasi inter-seismik di daerah Bengkulu bagian utara setelah satu dekade kejadian deformasi post-seismik gempa bumi Bengkulu 2007 (Mw 8,4) dengan menggunakan pemantauan Global Positioning System (GPS). Pengambilan data GPS dilakukan pada 5 titik pengamatan yaitu titik BNTL, IPUH, SBLT, MURI dan KTHN selama tahun 2018-2020. Data GPS tersebut diolah menggunakan perangkat GAMIT/GLOBK. Hasil penelitian memperlihatkan bahwa setelah lebih 10 tahun kejadian gempa bumi tahun 2007 (Mw 8,4), daerah Bengkulu bagian utara saat sekarang mengalami fase inter-seismik dalam siklus gempa bumi yang ditandai dengan deformasi inter-seismik pada 5 stasiun GPS. Vektor pergerakan pada stasiun ini kelihatan seragam dengan kecepatan rata-rata $20 \mathrm{~mm} /$ tahun menuju arah timur laut, sesuai dengan pergerakan relatif plate tektonik Indo-Australia terhadap Eurasia. Hasil penelitian lain menunjukkan bahwa tidak terlihat deformasi co-seismik akibat dari 285 gempa bumi dengan kekuatan $\geq 4.0$ dari bulan Januari 2018 sampai November 2020 di daerah Bengkulu bagian utara. Untuk keperluan mitigasi dan perencanaan wilayah, maka perlu dilakukan penelitian yang kontinu serta menambah titik pengamatan GPS dalam rangka pemetaan kawasan pengumpulan stress maupun pengeluaran energy melalui gempa bumi di Bengkulu.
\end{abstract}

Kata kunci: Co-seismik; deformasi; Gempa bumi; GPS; inter-seismik.

\begin{abstract}
Research on earthquake cycle including co-seismic, post-seismic and inter-seismic phases, is very important to be carried out. This study aims to observe inter-seismic deformation in the northern part of Bengkulu after a decade of post-seismic deformation events in the 2007 Bengkulu earthquake (Mw 8.4) using Global Positioning System (GPS) monitoring. GPS data collection was carried out at 5 observation stations, namely BNTL, IPUH, SBLT, MURI and KTHN stations during 2018-2020. The GPS data were processed using GAMIT/GLOBK software. The result shows that after more than 10 years of the 2007 earthquake (Mw 8.4), the northern Bengkulu area is currently experiencing an interseismic phase of the earthquake cycle characterized by inter-seismic deformation at 5 GPS stations. The vector deformations appear to be uniform with an average velocity of $20 \mathrm{~mm} / \mathrm{year}$ toward the northeast, consistent with relative motion of the Indo-Australian tectonic plate to Eurasia plate. The other result show that there is no visible co-seismic deformation as results of 285 earthquakes $M w$ $\geq 4.0$ during January 2018 to November 2020. For the purposes of mitigation and regional planning, it is necessary to carry out continuous research and add more GPS stations that will help to map the area of stress accumulation and energy released by earthquakes in Bengkulu region.
\end{abstract}

Keywords: Co-seismic; deformation; earthquake; GPS; inter-seismic.

\footnotetext{
*Korespondensi: asharml@unib.ac.id

Diajukan : 12 Desember 2020

Diterima : 18 Januari 2021

Diterbitkan : 31 Maret 2021
} 


\section{PENDAHULUAN}

Pulau Sumatra memiliki populasi lebih kurang 50 juta orang atau sekitar $21 \%$ dari total jumlah penduduk Indonesia (BPS, 2010). Pada akhirakhir ini sebagain penduduk di Sumatra menjadi korban akibat gempa-gempa besar dan sebahagian masyarakat lainnya yang berada pada wilayah rawan gempa bumi dapat bertahan dan dapat menyelamatkan diri dari bahaya gempa-gempa besar pada zona subduksi, seperti gempa bumi Sumatra-Andaman yang terjadi pada tahun 2004, Mw 9,2 (Lubis dkk., 2011), gempa Nias pada tahun 2005, Mw 8,7 (Briggs dkk., 2006) dan gempa Bengkulu dengan kekuatan Mw 8.5 pada 12 september tahun 2007 (Lubis dkk., 2013). Meskipun demikian, kita masih perlu mempersiapkan diri terhadap bahaya gempa bumi dan meneliti kemungkinan sumber-sumber gempa bumi di masa yang akan datang. Selama ini kebanyakan penelitian tentang gempa hanya difokuskan pada daerah laut di zona subduksi Sumatra (misalnya Prawirodirjo dkk., 1997; Bock dkk., 2003; Chlieh dkk., 2008).

Penelitian di daerah subduksi, selama dekade terakhir, dengan jaringan Global Positioning System (GPS) SuGAr (yang diinisiasi oleh Caltech dan LIPI) telah dilakukan dan telah terinstal disepanjang pulau-pulau terluar bagian barat pulau Sumatra. Jaringan ini bertujuan untuk menghitung akumulasi regangan (energi) di sepanjang daerah subduksi Sumatra dan memperkirakan besaran gempa yang akan terjadi. Jaringan ini telah berhasil mendeteksi deformasi seismik pada saat inter-seismik (sebelum gempa), co-seismik (saat gempa) dan post-seismik (pasca gempa) yang terkait dengan sejumlah gempa besar pada zona subduksi Sumatra (Briggs dkk., 2006; Konca dkk., 2008; Lubis dkk., 2013). Disamping itu, jaringan GPS SuGAr telah berhasil memperkirakan besaran energi yang akan terlepas pada saat gempa pada Nias tahun 2005 dan gempa Bengkulu pada 2007 (Chlieh dkk., 2008).

Dari model Chlieh dkk. (2008) telah banyak ilmuwan yang membuat model tsunami untuk memperkirakan ketinggian tsunami di wilayah Sumatra Barat terutama untuk Kota Padang (misalnya: Borrero dkk., 2006; McCloskey dkk., 2008). Mengingat pada akhir-akhir ini terjadi peningkatan status seismik pada zona subduksi Sumatra untuk wilayah Bengkulu khususnya tahun 2018-2020 dan setelah satu dekade kejadian Gempa Bumi Bengkulu 2007 (Mw 8,4 ), maka penelitian tentang siklus gempa bumi dan status seismik yang berhubungan dengan fase inter-seismik, co-seismik dan post-seismik di daerah Bengkulu sangat diperlukan. Penelitian sebelumnya memperlihatkan bahwa dari hampir 10 tahun pada selang 2007-2016 daerah Bengkulu Utara terlihat pada stasiunstasiun GPS mengalami fase post-seismik (Lubis dkk., 2020). Oleh karena itu, penelitian tentang status seismik melalui kajian deformasi akibat pergerakan plate tektonik sangat diperlukan.

Salah satu cara untuk mengetahui status seismik yakni melalui pengamatan deformasi tektonik yang berhubungan dengan kejadian siklus sebuah gempa bumi (deformasi interseismik, co-seismik dan post-seismik). Pengamatan deformasi ini dapat dilakukan dengan pendekatan Geodesi yaitu menggunakan teknologi Interferometry Synthetic Aperture Radar (InSAR) dan teknologi GPS. Teknologi InSAR adalah teknologi Geodesi yang dikembangkan untuk pengamatan deformasi dengan akurasi centimeter (Abidin, 2001). Namun, teknologi GPS memiliki orde ketelitian yang lebih tinggi dibandingkan dengan InSAR. Teknologi GPS dapat memberikan nilai vektor deformasi kerak bumi yang berhubungan dengan gempa bumi secara tiga dimensi yakni deformasi dalam arah horizontal dan vertikal dengan tingkat presisi sampai orde milimeter (Abidin dkk., 2009). Khusus untuk wilayah Sumatra yang mempunyai vegetasi yang banyak serta topografi yang kadang curam, metode InSAR kurang efektif untuk digunakan saat ini terutama untuk pengamatan deformasi inter-seismik. Disisi lain teknologi GPS dapat digunakan tanpa bergantung waktu dan cuaca, sehingga dalam pengamatan deformasi seismik di wilayah Bengkulu bagian utara dengan menggunakan teknologi GPS.

Tujuan dari penelitian ini adalah untuk mengamati deformasi seismic, baik itu deformasi inter-seismik maupun co-seismik di daerah Bengkulu bagian utara menggunakan metode GPS. Melalui pengamatan deformasi, akan dapat memahami pada fase mana sekarang ini di daerah Bengkulu bagian utara dalam hal aktifitas seismik dan kegempaan. Informasi ini akan memberikan input dalam pemodelan siklus gempa bumi dan pemodelan gempa bumi pada zona subduksi Sumatra yang berguna untuk menghitung perubahan stress akibat aktivitas 
tektonik di zona subduksi Sumatra. Kemudian informasi perubahan stress akan sangat berguna dalam memetakan akumulasi stress akibat pergeseran plat tektonik di sepanjang zona subduksi Sumatra. Pada akhirnya dengan mengetahui status seismik dalam hal kemungkinan rupture area dimasa yang akan datang pada kawasan ini akan dapat berguna dalam perencanaan pembangunan wilayah dan mitigasi bencana gempa bumi untuk para pemangku kepentingan.

\section{METODE PENELITIAN}

Pengumpulan data pada penelitian ini dilakukan dengan survei pada 5 titik stasiun pengamatan
GPS yang telah dibuat monument pemantau deformasi sebelumnya. Pengamatan GPS secara harian dilakukan pada selang waktu 2018-2020 dengan sampling data 30 detik. Peralatan yang digunakan yakni receiver GPS geodetik HiTarget CORS Vnet8 sebanyak 5 buah.

Pengamatan data satellite GPS dilakukan dengan pemasangan GPS geodetik pada monument pemantauan/stasiun yang terletak di daerah Bengkulu bagian Utara (Gambar 1). Pengumpulan data sekunder seperti data file Navigation Message Broadcast (brdc), file satellite precise phemeris ( $\mathrm{sp} 3$ ) yang merupakan data pendukung dan data titik ikat

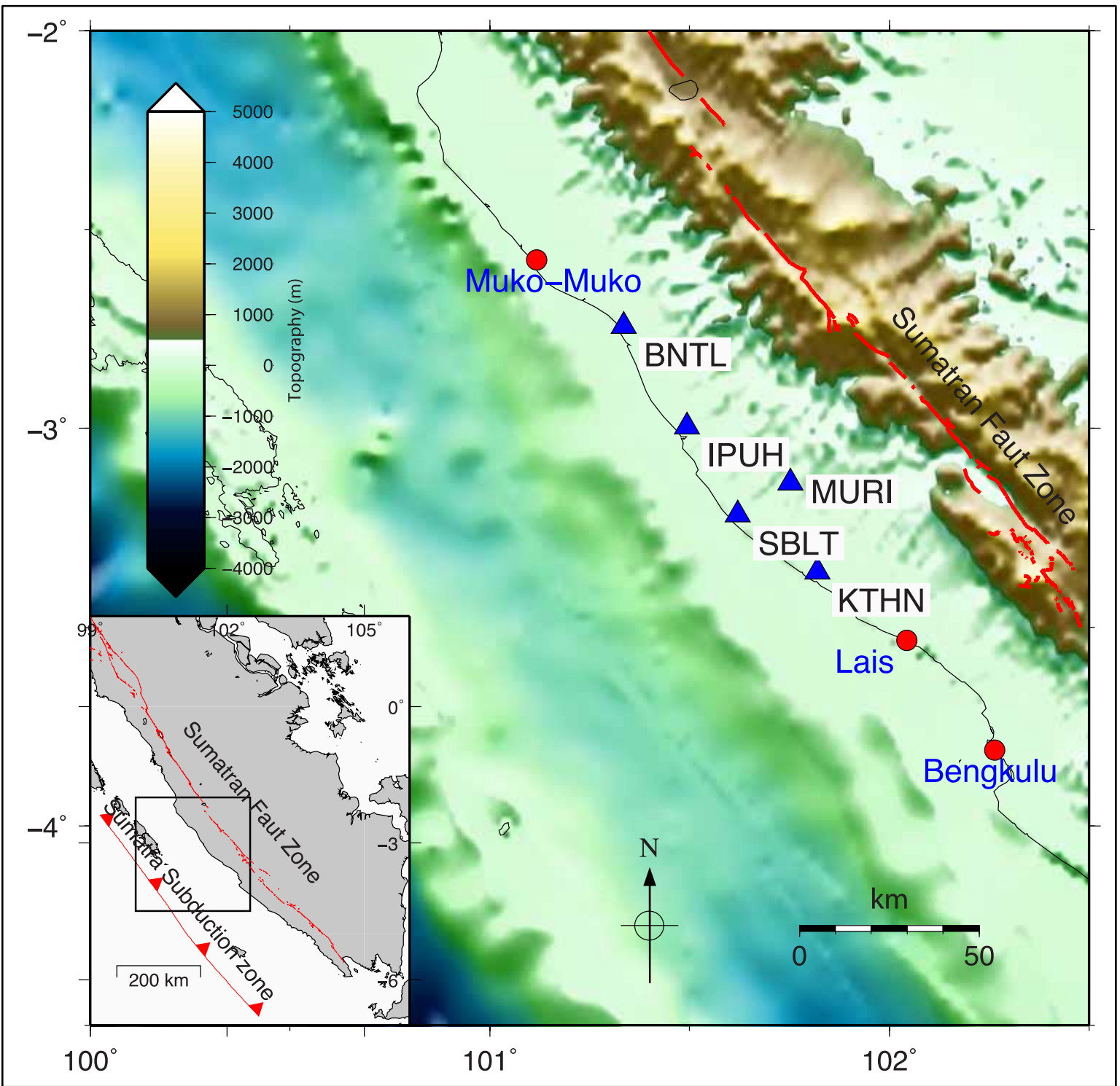

Gambar 1. Peta lokasi monument dan tempat stasiun GPS di daerah Bengkulu utara (segitiga biru). Warna peta merupakan ketinggian batimetry dan topography daerah penelitian. Inset map merupakan map daerah penelitian dalam area yang lebih luas dan kotak segi empat merupakan peta lokasi monument. 
IGS stasiun diunduh dari Scripps Orbit and Permanent Array Center (SOPAC). Sementara itu file atmosfer (atmdisp_YYYY), file gelombang pasang surut (otl_FES2004.grd), file pemodelan cuaca (vmf1grd.YYYY) yang dapat didownload melalui ftp://everest.mit.edu/pub/GRIDS/.

Pengolahan data GPS dilakukan dengan menggunakan software GAMIT/GLOBK (King and Bock, 2000). Sebelum pengolahan data dengan GAMIT/GLOBK, data pengamatan di cek kualitasnya dengan menggunakan software TEQC. Pengecekan data dilakukan untuk mengetahui waktu mulai dan berakhirnya sebuah pengamatan, nilai multipath yang terjadi, interval perekaman, dan total satelit. Untuk menjalankan program TEQC dilakukan pada terminal linux dan file observasi yang akan dilakukan pengecekan diletakkan dalam satu direktori dengan software teqc. Sebelum menjalankan perintah teqc, command promt dimasukan ke direktori teqc, kemudian dijalankan perintah: teqc $+q \mathrm{c}$ <observation file data GPS>

Pengolahan data dengan software GAMIT dengan sh_gamit. Hasil dari pengolahan data GPS dengan software GAMIT didapatkan berupa $h$-file. Kumpulan $h$-file yang diperoleh digunakan untuk pengolahan dengan perangkat lunak GLOBK untuk mendapatkan posisi harian dan estimasi kecepatan pergerakan stasiun pengamatan dalam komponen horizontal (arah utara dan timur). Pengolahan data $h$-file dengan GLOBK dapat dilakukan dengan perintah glorg.cmd dan globk.cmd. Hasil akhir pengolahan dengan GLOBK berupa file *.prt,*.log, dan *.org yang digunakan untuk menganalisis titik koordinat dan plot time series (Herring dkk., 2010).

Hasil pengolahan data survei GPS digunakan untuk menentukan kecepatan vektor pergeseran. Kecepatan vektor pergeseran pada fase interseismik pada masing-masing stasiun pengamatan yang dapat ditentukan dengan metode least squared untuk komponen horizontal (arah utara $(V n)$ dan timur $(V e))$.

\section{HASIL}

Hasil pengolahan data GPS dengan menggunakan perangkat GAMIT/GLOBK dapat dilihat pada hasil time series posisi harian dari setiap titik pengamatan GPS. Hasil posisi harian secara time series yang telah diolah berupa perubahan posisi harian dalam komponen horizontal yaitu komponen arah utara dan arah timur. Dari posisi stasiun GPS dalam dua komponen ini, maka pergerakan posisi tahunan pada komponen arah utara dan arah timur dapat dihitung. Kemudian vektor pergerakan interseismik secara horizontal juga dapat diperkirakan.

Posisi harian GPS untuk 5 titik pengamatan dapat dilihat pada Gambar 2 sampai Gambar 6 relatif terhadap International Terrestrial Reference Frame (ITRF) 2008. Dapat dilihat bahwa ada sebahagian data GPS yang tidak dapat diperoleh dikarenakan pada waktu-waktu tersebut stasiun pengamtan GPS mengalami gangguan terhadap tidak tersedianya power supply untuk peralatan GPS geodetik dikarenakan charger solar panel tidak dapat berfungsi.

Secara umum dapat dilihat bahwa pada Gambar 2 sampai Gambar 6 tidak terlihat pegeseran/perpindahan pada stasiun-stasiun GPS yang berkaitan dengan gempa bumi yang ditandai dengan adanya offset perubahan posisi yang disebut dengan deformasi co-seismik akibat gempa-gempa bumi terkini khususnya tahun 2018-2020 di daerah Bengkulu bagian utara. Hal ini mungkin diakibatkan oleh gempa bumi yang terjadi relative lebih kecil sehingga offset deformasi karena gempa bumi masih kecil.

Pada Gambar 2 dapat dilihat posisi GPS secara time series untuk stasiun pengamatan di Bantal (BNTL) Bengkulu Utara bahwa posisi tahunan pada daerah ini untuk komponen utara bergerak sebesar $8,34 \pm 0,60 \mathrm{~mm} /$ tahun dan untuk komponen timur bergerak sebesar 20,91 \pm $0,74 \mathrm{~mm} /$ tahun. Data time series untuk posisi harian GPS di stasiun IPUH (daerah Ipuh, Bengkulu Utara) dapat dilihat pada Gambar 3 yang pada gambar ini menunjukkan bahwa pergerakan tahunan GPS untuk komponen utara bergerak sejauh $12,22 \pm 0,23 \mathrm{~mm} /$ tahun dan komponen timur sejauh 17,06 $\pm 0,28 \mathrm{~mm} /$ tahun.

Pada Gambar 4 dapat dilihat posisi harian GPS untuk stasiun pengamatan di daerah Seblat (SBLT) Bengkulu Utara secara time series dari tahun 2018-2020. Dapat dilihat bahwa pergerakan posisi tahunan GPS stasiun SBLT untuk komponen utara bergerak sebesar 11,65 \pm $0,24 \mathrm{~mm} / \mathrm{tahun}$ dan komponen timur sebesar $18,87 \pm 0,29 \mathrm{~mm} /$ tahun .

Sementara itu pada Gambar 5 diperlihatkan posisi tahunan GPS untuk stasiun pengamatan 


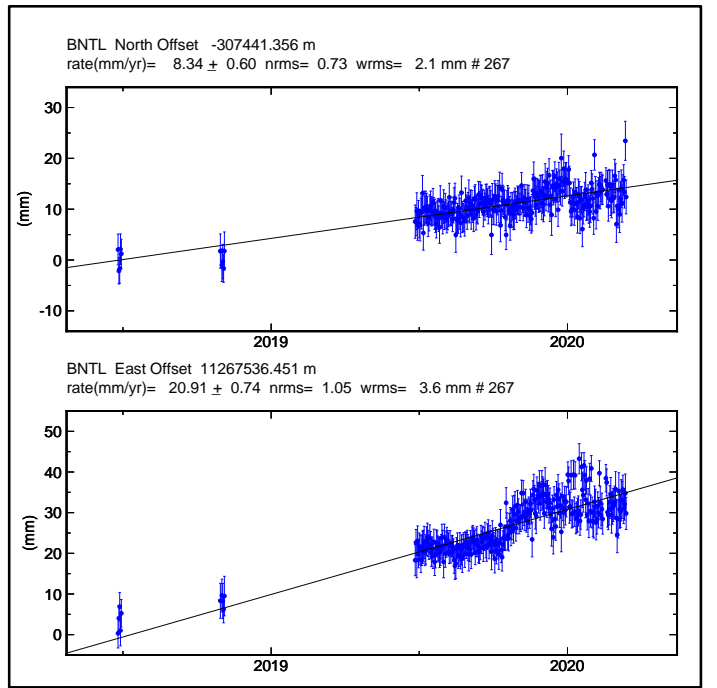

Gambar 2. Posisi harian GPS pada stasiun daerah Bantal (BNTL) untuk masing-masing komponen utara dan timur.

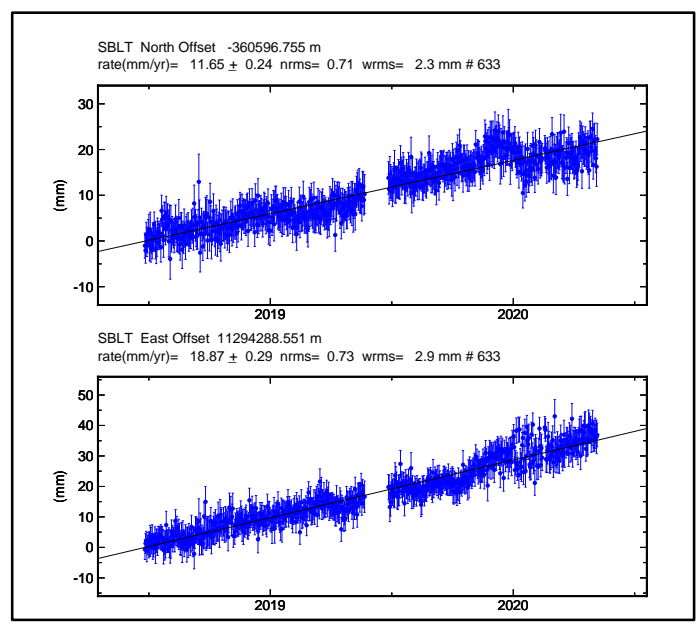

Gambar 4. Posisi harian GPS pada stasiun daerah Seblat (SLBT) untuk masing-masing komponen utara dan timur.

MURI yang memperlihatkan adanya penuruan pergerakan dimana hal ini konsistent dengan kerangka pergerakan plate tektonik pada daerah ini. Pergerakan tahunan pada stasiun MURI untuk komponen utara bergerak sebesar 9,81 \pm $0,39 \mathrm{~mm} /$ tahun dan komponen timur sebesar $15,69 \pm 0,47 \mathrm{~mm} /$ tahun

Pada Gambar 6 diperlihatkan posisi time series GPS pada stasiun Ketahun (KHTN). Pergerakan tahunan pada stasiun ini relative sama dengan peregrakan pada stasiun SBLT yang mana vektor pergerakan untuk komponen utara bergerak sebesar 10,32 $\pm 0,33 \mathrm{~mm} /$ tahun, sedangkan pergerakan untuk komponen timur bergerak sebesar $18,18 \pm 0,42 \mathrm{~mm} /$ tahun .

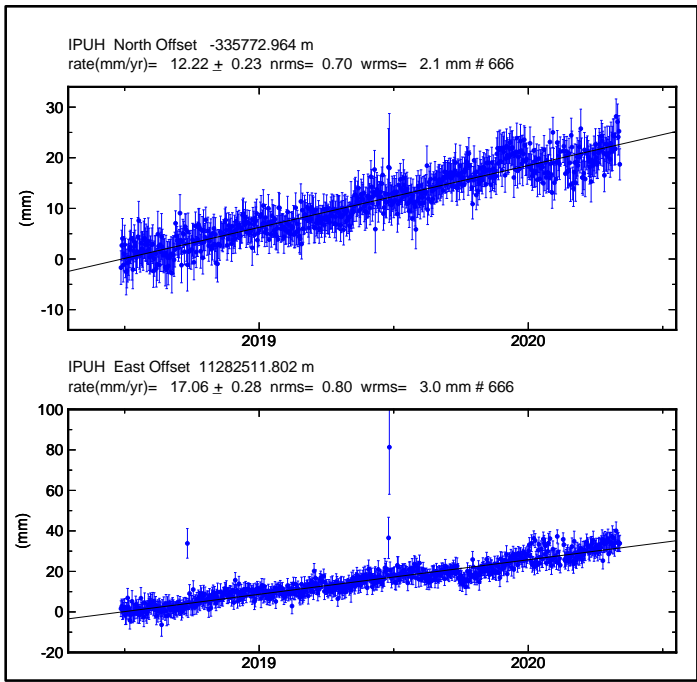

Gambar 3. Posisi harian GPS pada stasiun daerah Ipuh (IPUH) untuk masing-masing komponen utara dan timur.

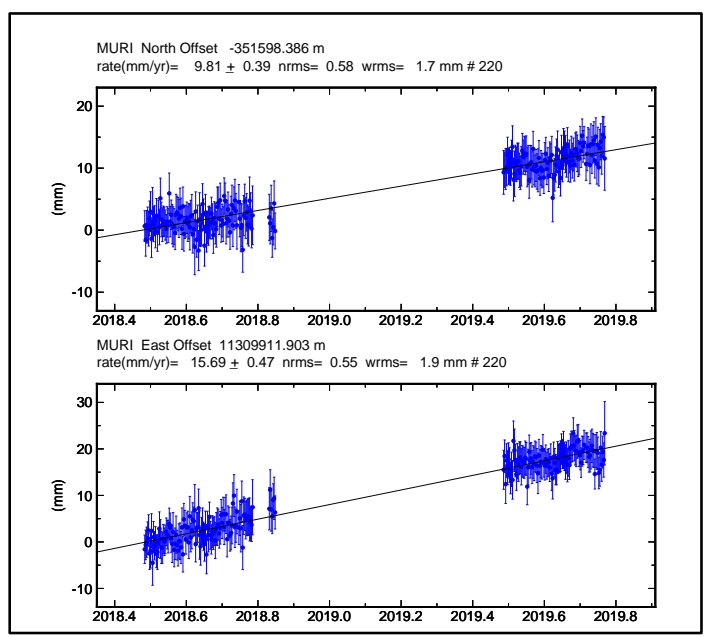

Gambar 5. Posisi harian GPS pada stasiun daerah Air Muring (MUPI) untuk masing-masing komponen utara dan timur.

Berdasarkan hasil pergerakan untuk komponen utara dan timur (Tabel 1), maka vektor kecepatan pergerakan pada fase inter-seismik pada 5 stasiun pengamatan GPS dapat ditentukan (Gambar 7). Hasil perhitungan vektor kecepatan pergeseran titik-titik pengamatan menunjukkan bahwa setiap titik pengamatan memiliki nilai kecepatan pergerakan yang berbeda-beda. Dapat kita lihat pada Gambar 7 pergerakan inter-seismik relatif terhadap ITRF 2008 secara umum kelihat seragam dengan kecepatan rata-rata $20 \mathrm{~mm} /$ tahun menuju arah timur laut, sesuai dengan pergerakan relative plate tektonik Indo-Australia terhadap Eurasia. 


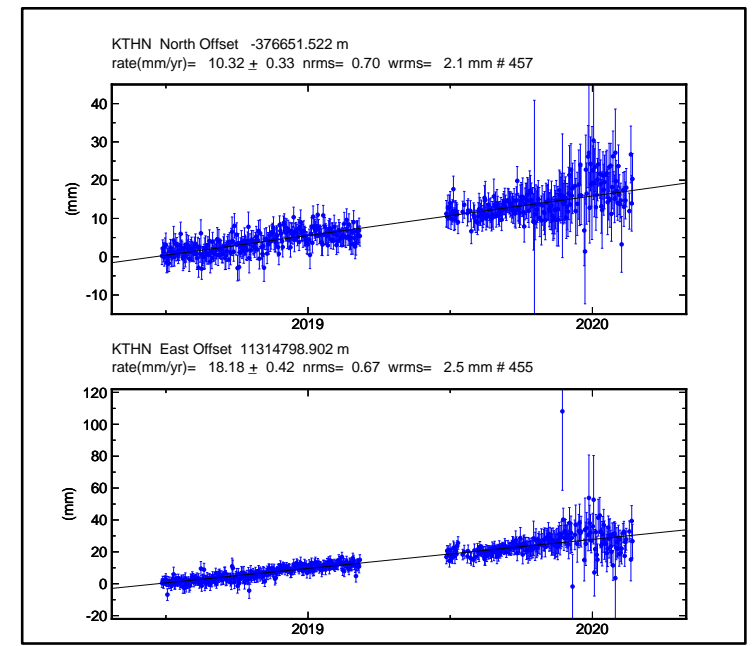

Gambar 6. Posisi harian GPS pada stasiun daerah Ketahun (KTHN) untuk masing-masing komponen utara dan timur.
Kecepatan deformasi inter-seismik ini memperlihatkan deformasi yang terjadi di sepanjang wilayah pesisir Bengkulu bagian utara secara horizontal. Hasil deformasi yang didapatkan dari pengamatan GPS menunjukkan bahwa vektor pergeseran bergerak ke arah timurlaut yang mengartikan bahwa arah vektor pergeseran model yang dihasilkan searah dengan arah pergerakan lempeng Indo-Australia yang mensubduksi lempeng Eurasia (Prawirodirdjo dkk., 1997).

Hasil kecepatan pergerakan stasiun titik pengamatan GPS masih dipengaruhi oleh nilai rotasi Blok Sunda. Untuk mendapatkan kecepatan pergerakan stasiun titik pengamatan GPS yang hanya dipengaruhi oleh zona subduksi

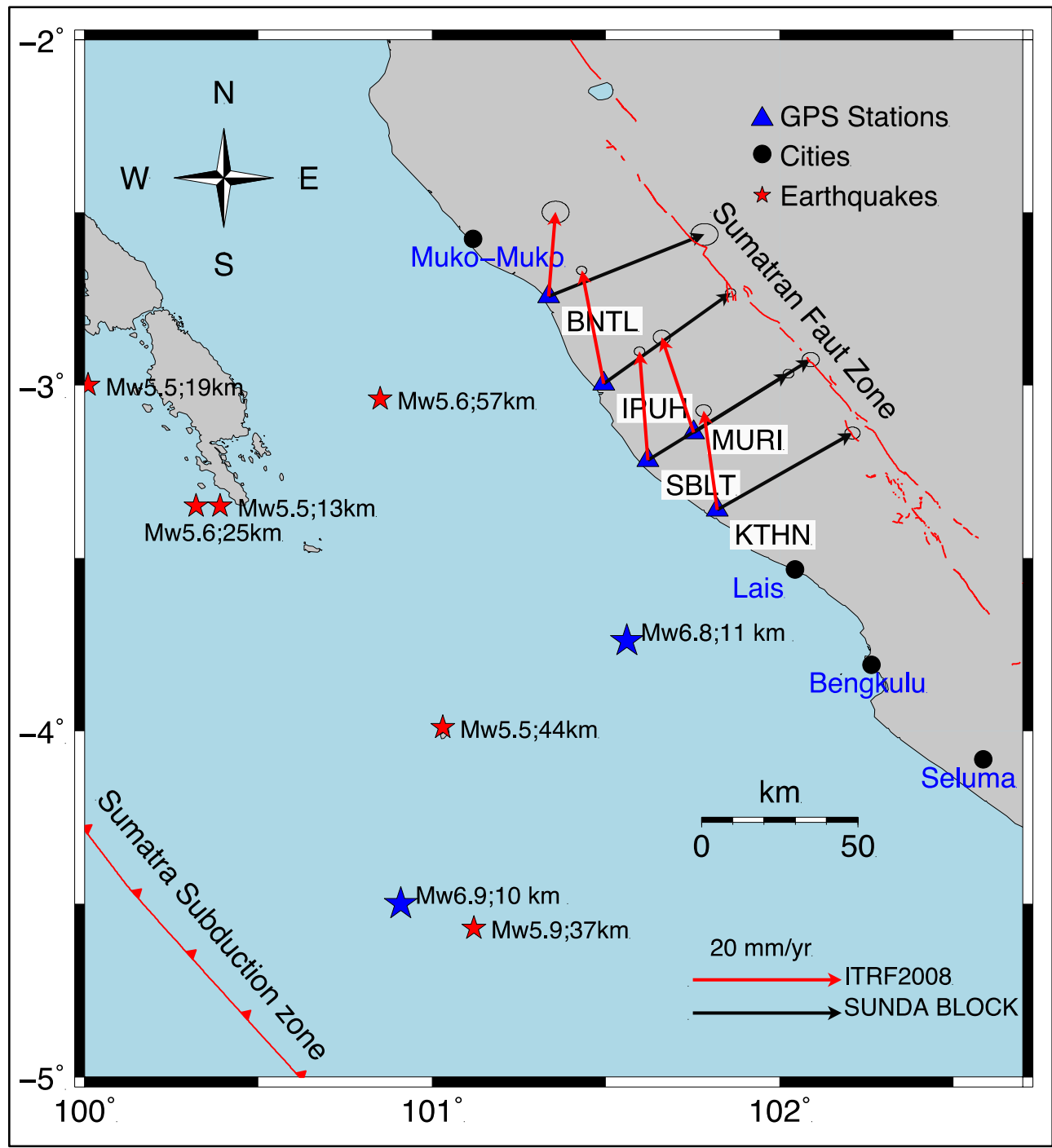

Gambar 7. Vektor pergerakan GPS stasiun di daerah Bengkulu Utara relative terhadap ITRF 2008 (hitam) dan terhadap Sunda Block (merah). Bintang biru merupakan episenter gempa bumi 19 Agustus 2020, Mw 6,9 dan Mw 6,8 dan bintang merah episenter gempa bumi Mw 5,5-6.0 tahun 2018-2020. 
Tabel 1. Kecepatan inter-seismik pada stasiun GPS relatif terdadap ITRF2008 dalam mm/tahun, dan $\sigma$ merupakan error pengukuran GPS.

\begin{tabular}{cllllccc}
\hline No & Stasiun & Lat $\left({ }^{\circ}\right)$ & Lon $\left({ }^{\circ}\right)$ & $\boldsymbol{V n}$ & $\boldsymbol{\sigma V n}$ & $\boldsymbol{V e}$ & $\boldsymbol{\sigma V \boldsymbol { e }}$ \\
\hline 1 & IPUH & $-2,9957$ & 101,4931 & 17,06 & 12,22 & 0,28 & 0,23 \\
2 & KTHN & $-3,3609$ & 101,8200 & 18,18 & 10,32 & 0,42 & 0,33 \\
3 & SBLT & $-3,2176$ & 101,6207 & 18,87 & 11,65 & 0,29 & 0,24 \\
4 & BNTL & $-2,7433$ & 101,3357 & 20,91 & 8,34 & 0,74 & 0,60 \\
5 & MURI & $-3,1373$ & 101,7531 & 15,69 & 9,81 & 0,47 & 0,39 \\
\hline
\end{tabular}

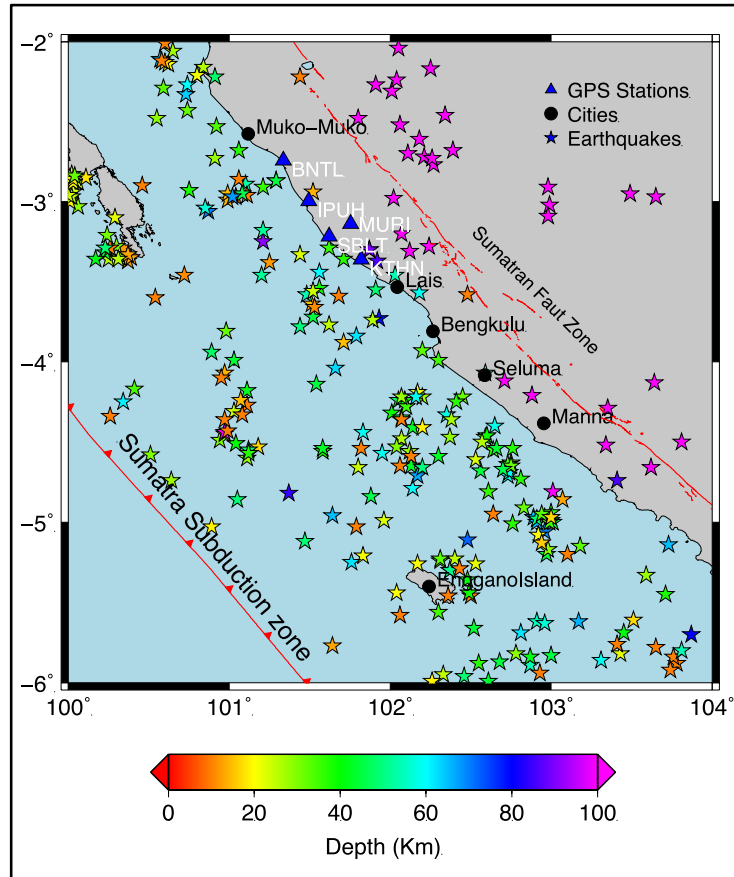

Gambar 8. Distribusi gempa bumi terhadap kedalaman di daerah Bengkulu.

Sumatra dan Sesar Sumtara saja, maka nilai kecepatan pergerakan yang didapatkan dari GPS perlu dikoreksi rotasi terhadap Blok Sunda.

Berdasarkan hasil pengamatan GPS yang ada di Indonesia khususnya wilayah Sumatera dan sekitarnya, vektor pergeseran Blok Sunda adalah $\pm 2 \mathrm{~cm} /$ tahun yang bergerak relatif ke arah timur dan arah selatan $\pm 3 \mathrm{~mm} /$ tahun (Simons dkk., 2007). Setelah dilakukan koreksi ini, maka kecepatan pergerakan dari 5 stasiun GPS bergerak lebih condong ke utara dengan kecepatan 12-15 mm/tahun (Gambar 7). Dari sini dapat dilihat komponen pergerakan interseismik dari zona subduksi Sumatra maupun dari sesar Sumatra yang melintasi daerah Bengkulu.

Untuk melihat kaitan deformasi coseismik pada saat kejadian gempa bumi di daerah Bengkulu pada stasiun pemantau GPS (Gambar 1 dan Gambar 7), maka dilakukan studi sebaran gempa bumi yang signifikan berdasarkan data

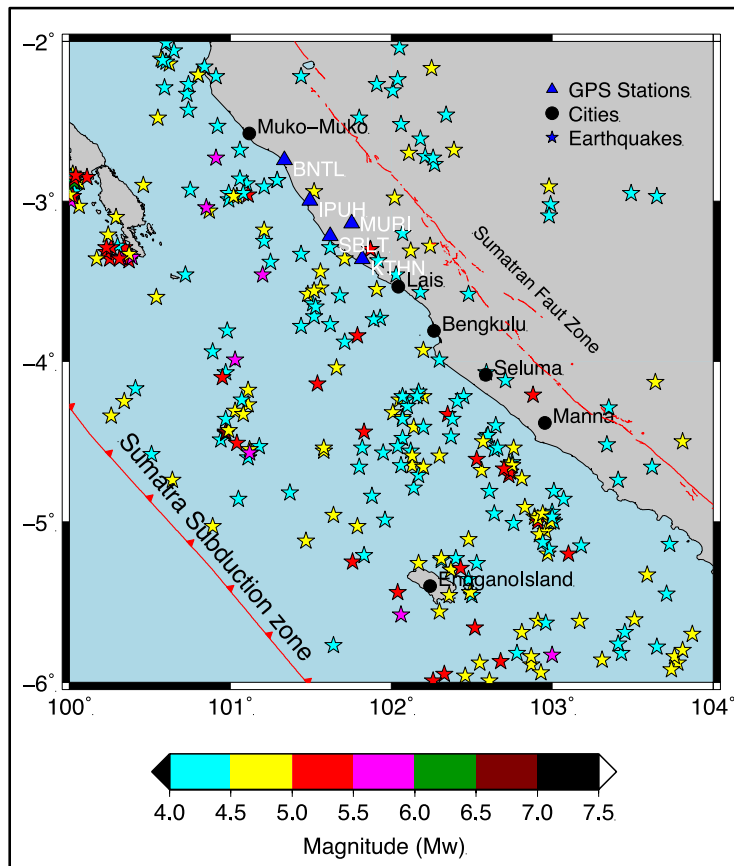

Gambar 9. Distribusi gempa bumi terhadap magnitude di daerah Bengkulu.

dari Badan Meterologi, Klimatologi, dan Geofisika (BMKG). Hasil pengamatan terhadap gempa bumi di daerah Bengkulu berdasarkan data gempa bumi dari BMKG terdapat sebanyak 285 gempa bumi dengan kekuatan $\geq 4.0$ dari bulan Januari 2018 sampai November 2020 (Gambar 8).

Episenter dan kedalaman gempa bumi diperlihatkan pada Gambar 8 dan Gambar 9. Dapat lihat pada Gambar 8 kedalaman gempa bumi bervariasi dari kedalaman $10 \mathrm{~km}$ sampai $100 \mathrm{~km}$. Gempa-gempa yang berada di Pulau Sumatra umumnya gempa dalam $(>100 \mathrm{~km})$ yang berasal dari zona penujaman subduksi Sumatra. Hanya terdapat 2 buah gempa bumi dangkal dengan kedalaman $15 \mathrm{~km}$ yang berasal dari patahan Sumatra. Namun, hal ini bisa menandakan bahwa di daerah Bengkulu terdapat dua sumber gempa bumi di mana sumber pertama dari pergerakan lempeng Indo-Australia 
(Bock dkk., 2003). Sementara sumber gempa bumi yang kedua dari sesar Sumatra yang melalui wilayah Bengkulu yakni patahan Musi (Segmen Musi) yang terletak di Kabupaten Kepahiang, patahan Manna (Segmen Manna) yang terletak di Kabupaten Bengkulu Selatan, dan patahan Ketahun (Segmen Ketahun) (Burton dan Hall, 2014).

Selama kurun waktu bulan Januari 2018 sampai November 2020 lebih dari 200 kejadian gempa bumi yang terjadi relative berkekuatan yang kecil ( $\mathrm{Mw}$ 4.0-5.0). Kemudian sekitar 34 kejadian gempa bumi berada pada kekuatan $\mathrm{Mw}$ 5.0-5.4 dan hanya sekitar 8 kejadian gempa bumi berada pada kekuatan $\mathrm{Mw}$ 5.5-6.0 (Gambar 7).

Selanjutnya dapat dilihat pada Gambar 7 gempa bumi yang terdekat dengan GPS stasiun dengan magnitude $\mathrm{Mw} 5.6$ terjadi pada tanggal 16 Desember 2019, akan tetapi karena gempa bumi ini sangat dalam yakni hampir mencapai $60 \mathrm{~km}$, maka pada stasiun GPS deformasi $\mathrm{co}$ seismik akibat gempa bumi tidak terdeteksi. Sementara itu, 2 kejadian gempa bumi di perairan barat Provinsi Bengkulu terjadi 19 Agustus 2020, pukul 05:23 dan 05:29 WIB dengan $\mathrm{Mw}$ 6,9 dan Mw 6,8 (lihat Gambar 7). Menurut BMKG pusat gempa bumi pertama terletak pada koordinat $100,91^{\circ} \mathrm{BT}$ dan $4,5^{\circ} \mathrm{LS}$ pada kedalaman $10 \mathrm{~km}$, sedangkan gempa bumi kedua terletak pada koordinat $101,56^{\circ}$ BT dan $3,74^{\circ}$ LS pada kedalaman $11 \mathrm{~km}$. Dapat dilihat pada Gambar 7 bahwa episenter gempa bumi kedua relatif lebih dekat dekat dengan stasiun pengamatan GPS di Ketahun, namun deformasi coseismik tidak dapat teramati dikarenakan 5 stasiun pengamatan GPS tersebut mengalami masalah pada waktu tersebut sehingga semua receiver dalam keadaan tidak berfungsi saat kejadi gempa bumi. Dengan demikian secara umum dapat lihat bahwa fase inter-seismik yang teramati pada stasiun GPS tidak terganggu dengan adanya kejadian gempa bumi selama tahun 2018-2020 di daerah Bengkulu bagian utara.

\section{PEMBAHASAN}

Dari hasil penelitian pengamatan posisi harian dan vektor deformasi yang terjadi pada 5 stasiun GPS yang terdapat di daerah Bengkulu Utara, secara umum dapat dilihat bahwa setelah lebih 10 tahun kejadian gempa bumi tanggal 12 September 2007 dengan magnitude Mw 8,4
(Lubis dkk., 2013) daerah Bengkulu bagian utara mengalami fase inter-seismik tanpa ada gangguan fase co-seismik. Penelitian sebelumnya memperlihatkan bahwa dari hampir 10 tahun pada selang 2007-2016 daerah Bengkulu Utara terlihat pada stasiun-stasiun GPS mengalami fase post-seismik (Lubis dkk., 2020).

Pada Gambar 7 diperlihatkan vektor pergerakan GPS stasiun di daerah Bengkulu Utara relatif terhadap dan terhadap Sunda Block (vektor merah merah). Dapat dilihat bahwa hasil memberikan pengetahuan terhadap kita bahwa zona subduksi Sumatra dan sesar Sumatra masing-masing memberikan kontribusi pergerekan pada stasiun pengamatan GPS dalam fase inter-seismik yang sedang berlangsung saat ini. Fase inter-seismik ini merupakan tahap awal dari suatu siklus gempa bumi. Pada fase ini sedang terjadi pengumpulan energi pada pertemuan patahan akibat pergerakan relatif patahan baik dari zona subduksi Sumatra dan sesar Sumatra. Akibat akumulasi energi ini yang dapat menyebabkan terjadinya gempa bumi dikemudian hari.

Kejadian-kejadian gempa bumi berada di daerah Sumatra khususnya daerah Bengkulu sangat dipengaruhi oleh penunjaman pada daerah subduksi Sumatra dan keberadaan sesar Sumatra. Secara litologi wilayah pesisir barat Bengkulu pada umumnya tersusun oleh batuan sedimen berumur Kuarter dan Formasi Bintunan yang terbuat dari aneka bahan seperti breksi, batugamping terumbu, batulempung tufan, berbatuapung, kayu terkersikkan berumur Plistosen. Guncangan gempa bumi pada umumnya untuk daerah dengan kondisi geologi seperti ini akan dirasakan lebih kuat karena batuan Kuarter yang telah mengalami pelapukan sehingga dapat memperkuat (amplifikasi) efek guncangan gempa bumi.

Oleh karena itu, penelitian tentang potensi kegempaan dengan memonitoring pergerakan inter-seismik maupun co-seismik dan fase postseismik sangat penting untuk dilakukan secara terus menerus melalui perekaman data GPS geodetik pada stasiun pemantau yang ada di daearah Bengkulu. Di samping itu, karena daerah Bengkulu sangat luas, maka perlu dilakukan penambahan titik pengamatan GPS untuk memetakan pengumpulan stress maupun zona pengeluaran energi secara spasial maupun secara temporal. 


\section{KESIMPULAN}

Telah dilakukukan penelitian untuk mengamati pengamatan deformasi inter-seismik setelah satu dekade kejadian gempa bumi Bengkulu 2007 (Mw 8,4) di daerah Bengkulu Bagian Utara menggunakan 5 stasiun pemantauan GPS geodetik selama 2018-2020. Dari hasil penelitian dapat disimpulkan bahwa wilayah pesisir pantai Bengkulu bagian utara megalami fase inter-seismik. Pada 5 titik pengamatan GPS yaitu titik BNTL, IPUH, SBLT, MURI dan KTHN menunjukkan deformasi inter-seismik bergeser ke arah timur laut atau menuju daratan dengan nilai kecepatan vektor pergerakan pada 5 titik pengamatan antara 8-12 $\mathrm{mm} / \mathrm{tahun}$ komponen utara dan antara 15-21 mm/tahun komponen timur. Secara umum vektor pergerakan pada fase inter-seismik terlihat relatif seragam dengan kecepatan rata-rata 20 $\mathrm{mm} /$ tahun menuju arah timur laut, sesuai dengan pergerakan relative plate tektonik Indo-Australia terhadap Eurasia.

Dari hasil penelitian yang telah dilakukan juga menunjukkan bahwa tidak terlihat pegeseran/perpindahan pada stasiun-stasiun GPS yang berkaitan dengan gempa bumi yang disebut dengan deformasi co-seismik akibat dari 285 gempa bumi dengan kekuatan $\geq 4,0$ dari bulan Januari 2018 sampai November 2020 di daerah Bengkulu bagian utara. Hal ini mungkin diakibatkan oleh gempa bumi yang terjadi relatif lebih kecil sehingga offset deformasi coseismik karena gempa bumi yang terjadi masih relative kecil dan jauh dari 5 stasiun pengamatan GPS. Sementara itu pada 2 kejadian gempa bumi di perairan barat Provinsi Bengkulu terjadi pada tanggal 19 Agustus 2020, dengan Mw 6,9 dan Mw 6,8 di daerah laut Bengkulu Utara, deformasi coseismik dari pengamatan GPS juga tidak dapat teramati dikarenakan stasiun pengamatan GPS mengalami gangguan terhadap tidak tersedianya power supply untuk peralatan GPS geodetic yang disebabkan charger solar panel tidak dapat berfungsi dengan baik.

Untuk kedepan perlu dilakukan penelitian lebih lanjut dengan menambah stasiun titik pengamatan GPS serta menambah waktu pengamatan dalam rangka pemetaan kawasan pengumpulan stress maupun pengeluaran energi secara spasial maupun secara temporal. Disamping itu penelitian tentang potensi kegempaan dengan memonitoring pergerakan inter-seismik maupun co-seismik dan fase post- seismik sangat penting untuk dilakukan secara terus menerus melalui perekaman data GPS geodetic pada stasiun pemantau yang ada di daearah Bengkulu.

\section{UCAPAN TERIMA KASIH}

Penulis mengucapkan banyak terima kasih kepada P2O LIPI yang telah memberikan pendanaan untuk pendirian monument stasiun GPS melalui program Demand Driven Research Grant (DDRG) tahun 2018 melalui kegiatan Coral Reef Rehabilitation and Management Program-Coral Triangle Initiative (COREMAPCTI), LIPI. Penulis juga mengucapkan terimakasih PEER USAID yang telah menyediakan peralatan GPS sehingga penelitian ini bisa terlaksana. Ucapan terima kasih juga kepada Jurusan Fisika FMIPA UNIB yang telah mendanai pengambilan data GPS di lapangan. Terima kasih banyak untuk Rio Saputra membantu pengambilan data GPS. Ucapan terima kasih juga kepada Scripps Orbit and Permanent Array Center (SOPAC) yang telah menyediakan data sekunder orbit GPS.

\section{DAFTAR PUSTAKA}

Abidin, H.Z., 2001. Geodesi Satelit. Jakarta: PT Pradnya Paramita.

Abidin, Z.H., Andreas, H., Meilano, I., Gamal, M., Gumilar, I., dan Abdullah, C.I., 2009. Deformasi Koseismik dan Pascaseismik Gempa Yogyakarta 2006 Dari Hasil Survei GPS. Jurnal Geologi Indonesia, 4(4), hal.275-284.

Briggs R. W., Sieh, K, Aron. J. M., Natawidjaja, D., Suwargadi, B., Hs, Y., Simon, M., Hananto, N., Suprihanyono, I., Prayudi, D., Avouac, J.P., Prawirodirdjo, L. dan Bock, Y., 2006. Deformation and slip along the Sunda megathrust in the Great 2005 Nias-Simeulue earthquake, Science, 311, hal.1897-1901.

BPS, 2010. Hasil sensus penduduk 2010. Jakarta: Badan Pusat Statistik Indonesia.

Bock, Y., Prawirodirdjo, L., Genrich, J.F., Stevens, C.W., McCaffrey, R., Subarya, C., Puntodewo, S.S.O., dan Calais, E., 2003. Crustal motion in Indonesia from Global Positioning System measurements, Journal of Geophysical Research, 108(B8), 2367.

Borrero J.C., Sieh, K., Chlieh, M., dan Synolakis, C.E., 2006. Tsunami Inundation Modeling for Western Sumatra, Proceedings 
of the National Academy of Sciences of the United States of America, 130, 19673-19677.

Burton, P.W., dan Hall, T.R., 2014. Segmentation of the Sumatran fault, Geophysical Research Letter, 41, 41494158, doi:10.1002/2014GL060242

Chlieh, M., Avouac, J.P., Sieh, K, Natawidjaja, D., dan Galetzka, J., 2008. Heterogeneous coupling of the Sumatran megathrust constrained by geodetic and paleogeodetic measurements, Journal of Geophysical Research, 113, B05305, doi:10.1029/2007JB004981.

Herring, T.A., King S.W., dan McClussky S.C., 2010. GLOBK Reference Manual. Massachusetts: Department of Earth, Atmospheric, and Planetary Science Massachusetts Institute of Technology.

King R., dan Bock, Y., 2000. Documentation for the GAMIT GPS analysis software. Massachusetts: Department of Earth, Atmospheric, and Planetary Science Massachusetts Institute of Technology.

Konca A. O., Avouac, J.-P., A Ozgun Konca, Jean-Philippe Avouac, Anthony Sladen, Aron J Meltzner, Sieh, K., Fang, P., Li, Z., Galetzka, J., Genrich, J., Chlieh, M., Natawidjaja, D.H., Bock, Y., Fielding, E.J., Ji, D., dan Helmberger, D.V., 2008. Partial rupture of a locked patch of the Sumatra megathrust during the 2007 earthquake sequence, Nature, 456, doi:10.1038/nature07572.

Lubis A.M., Isezaki, N., dan Sato, T., 2011. 2-D coseismic deformation field of the SumatraAndaman Earthquake $2004 \mathrm{Mw} 9.2$ derived from SAR observation, Remote Sensing Letter, 2(2), pp; 107-116,

Lubis, A.M., Hashima, A., dan Sato, T., 2013, Analysis of afterslip distribution following the 12 September 2007 southern Sumatra earthquake using poroelastic and viscoelastic media, Geophysical Journal International, 192(1), doi: 10.1093/gji/ggs020.

Lubis, A.M., Purwanto, E. Simatupang, K.R, dan Hermawan, I., 2020. Deformasi Postsesismik- Interseismik Secara Spasial Daerah Bengkulu Melalui Pengamatan GPS Periode 2007-2016, Positron, Under review.

McCloskey J., Antonioli, A., Piatanesi, A., Sieh, K., Steacy, S., Nalbant, S., Cocco, M., Giunchi, C., Huang, J., dan Dunlop, P., 2008.
Tsunami threat in the Indian Ocean from a future megathrust earthquake west of Sumatra, Earth Planet Science Letters, 265, 61-81.

Prawirodirdjo, L., Bock, Y., McCaffrey, R., Genrich, J., Calais, E., Steven, C. Puntodewo, S.S.O., Rais, J., Zwick, P., MacCaffrey, R., dan Fauzi., 1997. Geodetic Observations of interseismic strain segmentation at the Sumatra subduction zone, Geophysical Research Letters, 24(21), 2601-2604.

Simons, W. J. F., Socquet, A., Vigny, C., Amrosius, B.A.C., Abu, S. H., Promthong, C., Subarya, C., Sarsito, D.A., Matheussen, S., Morgan, P., dan Spakman, W., 2007. A decade of GPS in Southeast Asia: Resolving Sundaland motion and boundaries, Geophysical Research Letters, 112, B06420, doi:10.1029/2005JB003868. 